\title{
Efek Ekstrak Etanol Daun Gendola Merah (Basella alba L.) terhadap Kadar Kreatinin, Ureum dan Deskripsi Histologis Tubulus Ginjal Tikus Putih Jantan (Rattus norvegicus) Diabetes yang Diinduksi Streptozotocin
}

\section{Effect of Ethanolic Extract of Gendola Merah (Basella alba L.) Leaves on Creatinine, Urea, and Description of Histological Tubular Kidney of Diabetic Male Rats induced by Streptozotocin}

\author{
Joni Tandi ${ }^{*}$, Ayu Wulandari, Asrifa
}

Program Studi S1 Farmasi, STIFA Pelita Mas Palu

\author{
Article Info: \\ Received: 18 Agustus 2017 \\ in revised form: 28 Agustus 2017 \\ Accepted: 20 September 2017 \\ Available Online: 01 Oktober 2017 \\ Keywords: \\ Red gendola leaf, \\ creatinine, \\ urea, \\ histologis, \\ tubular kidney \\ Corresponding Author: \\ Joni Tandi \\ ProgramStudiS1Farmasi \\ STIFA Pelita Mas, Palu, \\ Indonesia \\ Email: \\ stifapelitamaspalu@yahoo.com
}

\begin{abstract}
The objective of this study is to determine the effect and the effective dose of ethanolic extract of Red Gendola (Basella alba L.) leaves on creatinine, urea and description of histological tubular kidney of diabetic male rats induced by streptozotocin.

30 male rats devided into six groups : groups I, II, and III were the control groups and groups IV, V, and VI were the experimental groups. Groups II, III, IV, V, and VI are given induction of STZ $40 \mathrm{mg} / \mathrm{kg} \mathrm{BW}$ in a single dose i.p on day 0. Normal control group I and negatif control group II were given only Sodium-CMC 0,5\%; positive control group III was given glibenclamide $0,45 \mathrm{mg} / \mathrm{kg} \mathrm{BW}$; group IV, V, and VI were given each extract at a dose of 100,200 , and $400 \mathrm{mg} / \mathrm{kg} \mathrm{BW}$ in p.o every day. The obtained data were analyzed using one way Anova test at the level of $95 \%$ early followed by LSD Post Hoc Test, and the level of regeneration of histological tubular kidney was observed by HE staining using Olympus BX-51 microscope with a scale of $100 \mu \mathrm{m}$ and scoring data result of kidney tubular damage levels were analyzed by Kruskal-Wallis test followed by Mann-Whitney test to see the differences between treatments.

The results showed that ethanolic extract of red gendola with dose of $100 \mathrm{mg}$ / kg BW give significant effect to decrease the creatinine content and 200 $\mathrm{mg} / \mathrm{kg} \mathrm{BW}$ give effect of decrease of ureum level of diabetic white male rats. Moreover, red gendola ethanolic extract has also an effect on cell regeneration in renal tubules with an effective dose of $400 \mathrm{mg} / \mathrm{kg} \mathrm{BW}$ on diabetic male rats.
\end{abstract}

Copyright $(\mathrm{C}) 2017$ JFG-UNTAD

This open access article is distributed under a Creative Commons Attribution (CC-BY-NC-SA) 4.0 International license.

How to cite (APA 6th Style):

Tandi J., Wulandari A., Asrifa. (2017). Efek Ekstrak Etanol Daun Gendola Merah (Basella alba L.) terhadap Kadar Kreatinin, Ureum dan Deskripsi Histologis Tubulus Ginjal Tikus Putih Jantan (Rattus norvegicus) Diabetes yang Diinduksi Streptozotocin. Jurnal Farmasi Galenika (Galenika Journal of Pharmacy), 3(2), 93-102. doi:10.22487/ j24428744.2017.v3.i2.8813 


\begin{abstract}
ABSTRAK
Penelitian ini bertujuan untuk mengetahui pengaruh pemberian serta dosis efektif ekstrak etanol daun gondola merah (Basella alba L.) terhadap kadar kretainin, ureum dan mendeskripsikan histologis tubulus ginjal tikus diabetes yang diinduksi streptozotocin (STZ).

Sebanyak 30 ekor tikus terbagi dalam 6 kelompok perlakuan, dengan rincian kelompok I, II, dan III sebagai kelompok kontrol dan kelompok IV, V, dan VI sebagai kelompok eksperimen. Kelompok II, III, IV, V dan VI diberikan induksi STZ $40 \mathrm{mg} / \mathrm{kg}$ BB secara i.p pada hari ke-0. Kelompok I: kontrol normal dan kelompok II: kontrol negatif diberi Na CMC 0,5\%; kelompok III: kontrol positif, diberi glibenklamid $0.45 \mathrm{mg} / \mathrm{kg}$ BB: kelompok IV; kelompok V; kelompok VI: diberi ekstrak masing-masing dengan dosis 100, 200 dan $400 \mathrm{mg} / \mathrm{kg}$ BB secara p.o setiap hari. Data kreatinin dan ureum yang diperoleh dianalisis menggunakan uji one way ANOVA pada taraf kepercayaan $95 \%$ dan dilanjutkan dengan uji Post Hoc LSD, dan gambaran tingkat kerusakan histologis tubulus ginjal diamati dengan pewarnaan HE menggunakan mikroskop Olympus BX-51 dengan skala $100 \mu \mathrm{m}$ dan data hasil skoring tingkat kerusakan tubulus ginjal dianalisis dengan uji Kruskal-Wallis dilanjutkan dengan uji Mann-Whitney untuk melihat perbedaan antar perlakuan.

Hasil penelitian diperoleh bahwa Ekstrak etanol daun gondola merah berpengaruh terhadap penurunan kadar kreatinin dan ureum tikus diabetes, dan dosis $100 \mathrm{mg} / \mathrm{kg}$ BB memberikan pengaruh yang signifikan terhadap penurunan kadar kretainin dan $200 \mathrm{mg} / \mathrm{kg}$ BB memberikan pengaruh penurunan kadar ureum tikus diabetes. Ekstrak etanol daun gondola dosis $400 \mathrm{mg} / \mathrm{kg} \mathrm{BB}$ memiliki efek terhadap regenerasi sel pada tubulus ginjal tikus diabetes.
\end{abstract}

Kata Kunci : Daun gondola merah, diabetes, kreatinin, ureum, histologis, tubulus ginjal, streptozotocin.

\section{PENDAHULUAN}

Obat herbal digunakan terutama karena mengandung beberapa bahan kimia yang berinteraksi baik dengan tubuh manusia atau sistem kekebalan tubuh untuk memerangi penyakit. Para ilmuwan mulai mempelajari komposisi kimia dari obat-obatan herbal tradisional. Penelitian ini, bersama-sama dengan pengetahuan modern biologi manusia, menyebabkan perkembangan obat-obatan modern (Dep Perdagangan RI, 2011). Tanaman yang telah diteliti mempunyai pengaruh dalam penurunan kadar hiperglikemia, kreatinin dan ureum ginjal. Salah satunya adalah tanaman gendola merah (Basella alba L.).

Hiperglikemia pada penderita DM menyebabkan keadaan stres oksidatif, dimana terjadi ketidakseimbangan antara Reactive Oxygen Species (ROS) terhadap antioksidan. Stres oksidatif menyebabkan peroksidasi lipid di membran sel endotel glomerulus. Hal ini menyebabkan kerusakan membran sel endotel glomerulus, sehingga fungsi filtrasi dari glomerulus menurun. Keadaan ini menyebabkan kadar ureum dan kreatinin serum meningkat (Robbins et al. 2003). Nefropati diabetis merupakan komplikasi mikrovaskuler tersering yang terjadi pada penderita DM dan menimbulkan beberapa kelainan pada struktur histologis ginjal, yakni perubahan pada glomerulus. (Scobie 2011).

Kreatinin adalah produk endogenus akhir dari metabolisme kreatin fosfat dimana kadarnya relatif lebih konstan. Ureum merupakan hasil utama dari metabolisme protein dalam tubuh. Kadar ureum dalam serum bergantung pada katabolisme (pemecahan) protein di dalam hati yang disekresikan ke dalam ginjal kemudian diekskresikan melalui urin, Kedua parameter ini menjadi salah satu parameter untuk menilai fungsi ginjal normal (Fuadi, 2009). Histologi adalah ilmu yang menguraikan struktur dari hewan secara spesifik dan hubungan antara struktur sel dan jaringan serta fungsinya. Histopatologi adalah ilmu yang mempelajari kondisi dan fungsi jaringan dalam hubungannya dengan penyakit. Histopatologi digunakan sebagai salah satu pertimbangan dalam penegakan diagnosis melalui hasil pengamatan terhadap jaringan yang diduga terganggu. Analisis kondisi histologi organ/jaringan dilihat dari perubahan morfologi, struktur dan indikasi kerusakan/infeksi/mutasi lainnya akibat pengaruh penyakit, bahan toksik atau proses-proses mutagenisis lainnya (Gerrit, 1988). 
Penelitian efek hipoglikemik ekstrak daun Basella rubra L. dengan induksi streptozotocin (STZ) yang dilakukan Nirmala et al (2009) dengan dosis pemberian $400 \mathrm{mg} / 100 \mathrm{Kg} \quad \mathrm{BB}$ signifikan mengembalikan kadar glukosa darah. Penelitian efek nefroprotektif ekstrak etanol Basella alba L. yang diinduksi gentamisin secara signifikan mengurangi peningkatan serum urin, natrium, kalium, kalsium, protein, kreatinin, urea, asam urat, dan GGT. Jaringan tingkat MDA juga berkurang secara signifikan (Kumar et al., 2013).

Uraian penelitian tersebut di atas menjadi dasar gagasan peneliti untuk melakukan penelitian lebih lanjut menggunakan hewan uji tikus putih jantan (Rattus norvegicus) diabetes yang diinduksi streptozotocin $40 \mathrm{mg} / \mathrm{kg}$ BB dengan variasi dosis ekstrak daun gendola merah (Basella alba L.), yaitu $100 \mathrm{mg} / \mathrm{kg} \mathrm{BB}, 200 \mathrm{mg} / \mathrm{kg}$ BB dan $400 \mathrm{mg} / \mathrm{kg} \mathrm{BB}$.

\section{METODE PENELITIAN}

Alat

Alat-alat kaca (Pyrex), ayakan mesh nomor 40, bejana maserasi, centrifuge, photometer 5010 (Roche $\left.{ }^{\circledR}\right)$, incubator, rotary vacuum evaporator, timbangan analitik (precisa), dan waterbath.

\section{Bahan}

Aquadest, asam klorida, aqua pro injeksi, besi (III) klorida,citrate-buffer saline, daun gendola merah (Basella alba L.) yang diperoleh di sekitar kota Palu Provinsi Sulawesi Tengah, dragendrof LP, etanol absolute $96 \%$, eter, eosin, Formalin $10 \%$, glibenklamid (Indofarma), hematoxylin, LiebermannBurchard, serbuk magnesium, Na CMC, Reagen Kit Kreatinin, Reagen Kit Ureum, Streptozotocin.

\section{Pembuatan Larutan Induksi Streptozotocin}

Streptozotocin ditimbang sebanyak 0,32 gram lalu dilarutkan menggunakan citrate-buffer saline dengan $\mathrm{pH}$ 4,5 lalu diinduksikan pada tikus melalui intraperitoneal (i.p). Dosis streptozotocin yaitu 40 $\mathrm{mg} / \mathrm{kg} \mathrm{BB}$.

\section{Pembuatan Suspensi Glibenklamid 0,45 mg/kg BB}

Dosis Glibenklamid pada manusia dewasa adalah $5 \mathrm{mg}$ per hari, jika dikonversi pada tikus dengan berat 200 gram adalah 0,018 maka dosis glibenklamid untuk tikus adalah $0,45 \mathrm{mg} / \mathrm{kg}$ BB. Ditimbang serbuk tablet glibenklamid yang setara dengan 0,036 $\mathrm{mg}$ dan disuspensi dalam Na-CMC 0,5\% hingga $50 \mathrm{ml}$ kemudian dikocok hingga homogen.

\section{Pembuatan ekstrak daun gendola merah}

Serbuk simplisia daun gondola merah sebanyak 1061 gram dimaserasi menggunakan pelarut etanol 96\% selama 3 hari dengan terus dilakukan pengadukan berulang. Selanjutnya ekstrak disaring menggunakan kertas saring dan diperoleh filtrat dan residu. Filtrat yang diperoleh selanjutnya dipekatkan menggunakan rotary vacuum evaporator dengan suhu $60^{\circ} \mathrm{C}$. Kemudian dilanjutkan dengan penguapan menggunakan waterbath hingga diperoleh ekstrak kental daun gendola merah (Basella alba L.).

\section{Pengujian antidiabetes}

Tikus dipuasakan 5 jam sebelum diukur kadar glukosa darah, kemudian diambil darah melalui vena ekor dan diteteskan pada stik glukometer. Dalam waktu 10 detik, kadar glukosa darah secara otomatis terukur dan hasilnya dapat dibaca pada monitor glukometer.

\section{Analisis data}

Data yang diperoleh berupa kadar kreatinin dan ureum darah tikus putih jantan (Rattus norvegicus) sebelum diinduksi STZ dan setelah diinduksi STZ. Analisis data dilakukan dengan menggunakan uji statistik one way ANOVA pada tingkat kepercayaan $95 \%$. Uji ini digunakan untuk mengetahui adanya perbedaan antar kelompok perlakuan dan dilanjutkan dengan uji lanjut post hoc Least Significant Difference (LSD). Data dianalisis menggunakan program SPSS 23.

Data hasil pemeriksaan mikroskopis yang diperoleh berupa data scoring gambaran tingkat kerusakan histologis sel pada tubulus ginjal tikus putih jantan, selanjutnya dianalisis menggunakan uji non-parametrik Kruskall Wallis dan dilanjutkan dengan uji Mann Whitney untuk mengetahui perbedaan diantara kelompok perlakuan.

\section{HASIL DAN PEMBAHASAN}

Penelitian ini bertujuan untuk mengamati pengaruh terhadap kadar kreatinin dan ureum tikus yang diberi variasi dosis ekstrak daun gendola merah akibat pemberian induksi STZ dosis $40 \mathrm{mg} / \mathrm{kg}$ BB selama 21 hari. Pengujian ini dilakukan dengan uji praklinik menggunakan hewan uji tikus putih jantan (Rattus norvegicus). Penelitian ini diawali dengan pengukuran kadar ureum dan kreatinin darah awal yakni pada hari ke-0 untuk mengetahui kadar ureum dan kreatinin normal tikus sebelum perlakuan dan setelah tikus diberi perlakuan. Pemberian perlakuan sesuai kelompok dilakukan selama 21 hari dan 
dilakukan pengukuran kadar kreatinin dan ureum pada hari ke-7 setelah perlakuan. Untuk mengetahui pengaruh bahan uji terhadap kadar ureum dan kreatinin akibat paparan STZ dimana terdapat perbedaan yang signifikan dengan kontrol negatif yang ditandai dengan nilai terhadap kadar ureum dan kreatinin yang tidak melebihi normal. Data yang diperoleh dianalisis statistik dengan uji one way ANOVA pada taraf kepercayaan $95 \%$.

Hasil uji analisis one way anova semua kelompok menunjukkan adanya perbedaan yang tidak signifikan pada kadar kreatinin awal (baseline) dengan nilai probabilitas adalah 0.169 ( $p>0.05)$ (Tabel 1) dan menunjukkan perbedaan yang signifikan pada kadar ureum awal dengan nilai probabilitas adalah $0.000 \quad(\mathrm{p}<0.05) \quad($ Tabel 2), sehingga dilanjutkan analisis data menggunakan Post Hoc Test. Hasil analisis Post Hoc Test LSD kadar ureum menunjukkan bahwa kelompok ekstrak 100 $\mathrm{mg} / \mathrm{kg}$ BB berbeda signifikan dengan kontrol positif tetapi berbeda tidak signifikan terhadap kelompok kontrol normal; negatif; ekstrak $200 \mathrm{mg} / \mathrm{kg}$ BB dan $400 \mathrm{mg} / \mathrm{kg}$ BB. Ekstrak $200 \mathrm{mg} / \mathrm{kg}$ BB dan 400 $\mathrm{mg} / \mathrm{kg}$ BB berbeda signifikan dengan kontrol normal dan positif tetapi berbeda tidak signifikan terhadap kelompok kontrol negatif dan ekstrak 100 mg/kg BB. Kelompok kontrol positif berbeda signifikan terhadap masing-masing kelompok perlakuan.

Hasil uji analisis one way anova hari ke-7 menunjukkan nilai probabilitas pada kadar kreatinin adalah $0.276(\mathrm{p}>0.05)$ dan kadar ureum adalah 0.200 ( $p>0.05)$. Hal ini menunjukkan adanya perbedaan yang tidak signifikan antara semua kelompok perlakuan, sehingga tidak perlu dilanjutkan uji analisis data menggunakan Post Hoc Test.

Hasil uji analisis one way anova hari ke-14 menunjukkan nilai probabilitas pada kadar kreatinin adalah 0.419 ( $\mathrm{p}>0.05)$, hal ini menunjukkan adanya perbedaan yang tidak signifikan antara semua kelompok perlakuan, sehingga tidak perlu dilanjutkan uji analisis data menggunakan Post Hoc Test. Hasil uji analisis one way anova menunjukkan nilai probabilitas pada kadar ureum adalah $0.000(\mathrm{p}<0.05)$, hal ini menunjukkan adanya perbedaan yang signifikan antara semua kelompok perlakuan, sehingga perlu dilanjutkan uji analisis data menggunakan Post Hoc Test. Hasil analisis Post Hoc Test LSD kadar ureum menunjukkan bahwa kelompok kontrol normal dan ekstrak 100 mg/kg BB menunjukkan adanya perbedaan yang signifikan terhadap semua kelompok perlakuan, sedangkan kelompok kontrol negatif; positif; ekstrak 200 mg/kg
BB dan $400 \mathrm{mg} / \mathrm{kg}$ BB menunjukkan adanya perbedaan yang tidak signifikan.

Hasil uji analisis one way anova hari ke-21 menunjukkan nilai probabilitas pada kadar kreatinin adalah $0.008(\mathrm{p}<0.05)$ dan nilai probabilitas kadar ureum adalah $0.006(\mathrm{p}<0.05)$. Hal ini menunjukkan adanya perbedaan yang signifikan terhadap kadar kreatinin dan ureum diantara semua kelompok. Sehingga dilanjutkan analisis data menggunakan Post Hoc Test. Hasil uji lanjut Post Hoc Test LSD terhadap kadar kreatinin hari ke-21 menunjukkan bahwa kelompok dosis ekstrak $100 \mathrm{mg} / \mathrm{kg} \mathrm{BB}$ menunjukkan adanya perbedaan yang tidak signifikan antar kelompok perlakuan. Dosis ekstrak $200 \mathrm{mg} / \mathrm{kg}$ BB menunjukkan perbedaan yang signifikan terhadap dosis ekstrak $400 \mathrm{mg} / \mathrm{kg} \mathrm{BB}$, tetapi berbeda tidak signifikan dengan kelompok kontrol normal; negatif; positif; dan ekstrak 100 mg/kg BB. Dosis ekstrak 400 $\mathrm{mg} / \mathrm{kg} \mathrm{BB}$ menunjukkan perbedaan yang signifikan terhadap kontrol negatif, kontrol positif dan dosis ekstrak $200 \mathrm{mg} / \mathrm{kg}$ BB, tetapi menunjukkan perbedaan yang tidak signifikan terhadap kontrol normal dan dosis $100 \mathrm{mg} / \mathrm{kg}$ BB. Hasil uji lanjut Post Hoc Test LSD terhadap kadar ureum hari ke-21 menunjukkan bahwa kelompok dosis ekstrak 100 $\mathrm{mg} / \mathrm{kg}$ BB menunjukkan perbedaan yang signifikan terhadap kontrol normal tetapi berbeda tidak signifikan terhadap kelompok kontrol positif; negatif; $200 \mathrm{mg} / \mathrm{kg}$ BB dan $400 \mathrm{mg} / \mathrm{kg}$ BB. Dosis ekstrak $200 \mathrm{mg} / \mathrm{kg}$ BB menunjukkan perbedaan yang signifikan dengan dosis ekstrak $400 \mathrm{mg} / \mathrm{kg}$ BB tetapi berbeda tidak signifikan terhadap kelompok kontrol normal; positif; negatif; $100 \mathrm{mg} / \mathrm{kg}$ BB. Dosis ekstrak $400 \mathrm{mg} / \mathrm{kg}$ BB menunjukkan perbedaan yang signifikan terhadap kelompok normal dan dosis ekstrak $200 \mathrm{mg} / \mathrm{kg}$ BB tetapi berbeda tidak signifikan terhadap kelompok kontrol positif; negatif; 100 $\mathrm{mg} / \mathrm{kg} \mathrm{BB}$.

Hasil uji analisis one way anova hari ke-28 menunjukkan nilai probabilitas pada kadar kreatinin adalah $0.007(\mathrm{p}<0.05)$ dan nilai probabilitas kadar ureum adalah $0.014(\mathrm{p}<0.05)$. Hal ini menunjukkan adanya perbedaan yang signifikan terhadap kadar kreatinin dan ureum diantara semua kelompok. Sehingga dilanjutkan analisis data menggunakan Post Hoc Test. Hasil uji lanjut Post Hoc Test LSD terhadap kadar kreatinin hari ke-28 menunjukkan bahwa kelompok ekstrak $100 \mathrm{mg} / \mathrm{kg} \mathrm{BB;} 200 \mathrm{mg} / \mathrm{kg}$ $\mathrm{BB}$ dan $400 \mathrm{mg} / \mathrm{kg}$ BB berbeda tidak signifikan dengan kontrol normal dan positif, tetapi berbeda signifikan terhadap kelompok kontrol negatif, hal ini menunjukkan bahwa esktrak daun gendola merah 
memberikan pengaruh terhadap kadar kreatinin. Hasil uji lanjut Post Hoc Test LSD terhadap kadar ureum hari ke-28 menunjukkan bahwa kelompok ekstrak $100 \mathrm{mg} / \mathrm{kg}$ BB dan $400 \mathrm{mg} / \mathrm{kg}$ BB menunjukkan perbedaan yang tidak signifikan terhadap kontrol positif dan negatif tetapi berbeda signifikan dengan kontrol normal. Kelompok ekstrak $200 \mathrm{mg} / \mathrm{kg}$ BB berbeda tidak signifikan dengan kelompok kontrol normal dan positif, tetapi berbeda signifikan terhadap kelompok kontrol negatif dan ekstrak $400 \mathrm{mg} / \mathrm{kg} \mathrm{BB}$. Hal ini menunjukkan bahwa ekstrak daun gendola merah $200 \mathrm{mg} / \mathrm{kg}$ BB memberikan pengaruh yang lebih baik terhadap kadar ureum.

Tabel 1.Rerata kadar kreatinin darah tikus putih jantan (Rattus norvegicus)

\begin{tabular}{|c|c|c|c|c|c|c|c|}
\hline \multicolumn{8}{|c|}{ Rerata \pm SD Kadar Kreatinin $(\mathrm{mg} / \mathrm{dL})$} \\
\hline Hari & Kontrol & Kontrol & Kontrol Positif & Dosis 100 & Dosis 200 & Dosis 400 & $P$ \\
\hline ke- & Normal & Negatif & (Glibenklamid) & $\mathrm{mg} / \mathrm{Kg} \mathrm{BB}$ & $\mathrm{mg} / \mathrm{Kg} \mathrm{BB}$ & $\mathrm{mg} / \mathrm{Kg} \mathrm{BB}$ & \\
\hline 0 & $0.67 \pm 0.06$ & $0.68 \pm 0.06$ & $0.77 \pm 0.09$ & $0.68 \pm 0.08$ & $0.71 \pm 0.05$ & $0.63 \pm 0.04$ & 0.169 \\
\hline 7 & $0.67 \pm 0.03$ & $0.93 \pm 0.25$ & $0.80 \pm 0.14$ & $0.78 \pm 0.10$ & $0.82 \pm 0.17$ & $0.71 \pm 0.13$ & 0.276 \\
\hline 14 & $0.78 \pm 0.08$ & $0.72 \pm 0.06$ & $0.81 \pm 0.26$ & $1.00 \pm 0.42$ & $0.82 \pm 0.06$ & $0.69 \pm 0.08$ & 0.419 \\
\hline 21 & $0.86 \pm 0.13$ & $0.62 \pm 0.09$ & $0.68 \pm 0.06$ & $0.79 \pm 0.10$ & $0.75 \pm 0.14$ & $0.96 \pm 0.15$ & 0.008 \\
\hline 28 & $0.69 \pm 0.06$ & $0.84 \pm 0.08$ & $0.62 \pm 0.04$ & $0.68 \pm 0.07$ & $0.70 \pm 0.07$ & $0.62 \pm 0.11$ & 0.007 \\
\hline
\end{tabular}

Keterangan: Nilai $P>0,05=$ Berbeda Tidak Signifikan

Nilai $\mathrm{P}<0,05=$ Berbeda Signifikan

Tabel 2.Rerata kadar ureum darah tikus putih jantan (Rattus norvegicus)

\begin{tabular}{|c|c|c|c|c|c|c|c|}
\hline \multicolumn{8}{|c|}{ Rerata \pm SD Kadar Ureum $(\mathrm{mg} / \mathrm{dL})$} \\
\hline Hari & Kontrol & Kontrol & Kontrol Positif & Dosis 100 & Dosis 200 & Dosis 400 & D \\
\hline ke- & Normal & Negatif & (Glibenklamid) & $\mathrm{mg} / \mathrm{Kg} \mathrm{BB}$ & $\mathrm{mg} / \mathrm{Kg} \mathrm{BB}$ & $\mathrm{mg} / \mathrm{Kg} \mathrm{BB}$ & $P$ \\
\hline 0 & $32.2 \pm 2.02$ & $27.9 \pm 2.32$ & $39.92 \pm 4.76$ & $29.28 \pm 3.15$ & $27.54 \pm 2.54$ & $26 \pm 1.33$ & 0.000 \\
\hline 7 & $30.98 \pm 0.79$ & $40.36 \pm 12.31$ & $46.26 \pm 13.92$ & $40 \pm 4.63$ & $30.66 \pm 9.24$ & $39.2 \pm 9.79$ & 0.200 \\
\hline 14 & $33.3 \pm 4.22$ & $53.94 \pm 8.85$ & $55.24 \pm 11.74$ & $67.48 \pm 5.66$ & $50.42 \pm 8.46$ & $52 \pm 5.88$ & 0.000 \\
\hline 21 & $33.22 \pm 2.82$ & $61.56 \pm 14.59$ & $70.22 \pm 25.78$ & $64.58 \pm 9.91$ & $48.14 \pm 12.3$ & $77.42 \pm 17.0$ & 0.006 \\
\hline 28 & $34.84 \pm 1.28$ & $89.78 \pm 34.43$ & $58.72 \pm 25.42$ & $66.14 \pm 10.06$ & $46.52 \pm 12.74$ & $78.26 \pm 24.82$ & 0.014 \\
\hline
\end{tabular}

Keterangan: Nilai $\mathrm{P}>0,05=$ Berbeda Tidak Signifikan

Nilai $\mathrm{P}<0,05=$ Berbeda Signifikan

Hasil uji LSD menunjukkan bahwa ekstrak daun gendola merah memberikan pengaruh terhadap kadar kreatinin dan ureum tikus putih jantan diabetes dan ekstrak yang efektif memberikan pengaruh terhadap penurunan kadar kreatinin dan ureum adalah ekstrak dengan dosis $200 \mathrm{mg} / \mathrm{kg}$ BB (Gambar 1 dan 2). Penurunan kadar kreatinin dan ureum menunjukkan adanya pengaruh yang ditunjukkan oleh pemberian ekstrak dimana kadar kreatinin dan ureum lebih rendah dibandingkan kontrol negatif yang hanya diberikan $\mathrm{Na} \mathrm{CMC}$, hal ini diduga karena kandungan dalam ekstrak tanaman mengandung flavonoid dan fenol. dengan aktivitas antioksidan tinggi dan bekerja sebagai diuretikum sehingga meningkatkan laju filtrasi glomerulus. Senyawa flavonoid dapat mencegah kerusakan sel beta pankreas karena memiliki aktivitas antioksidan dengan cara menangkap atau menetralkan radikal bebas terkait dengan gugus $\mathrm{OH}$ fenolik sehingga dapat memperbaiki keadaan jaringan yang rusak (Sari, D.P. 2016). 


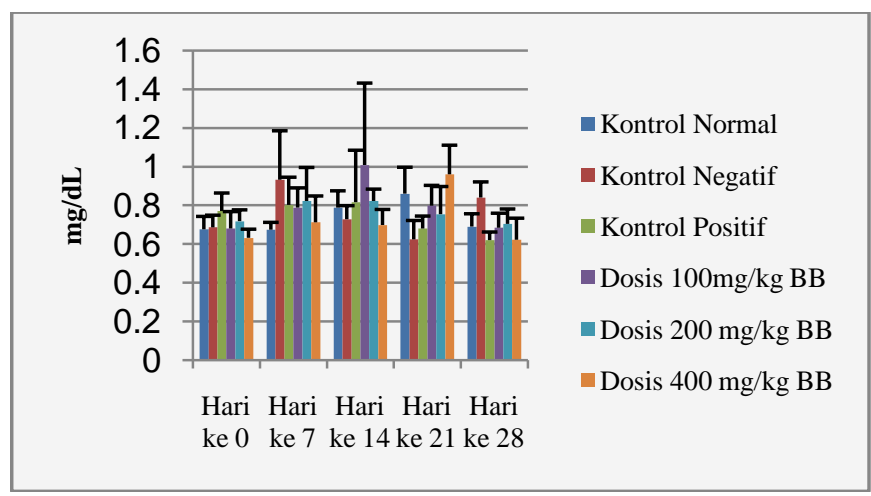

Gambar 1. Diagram profil kadar Kreatinin darah tikus putih jantan setelah perlakuanpada masingmasing kelompok hari ke-0, hari ke-7, hari ke14 , hari ke-21 dan hari ke-28.

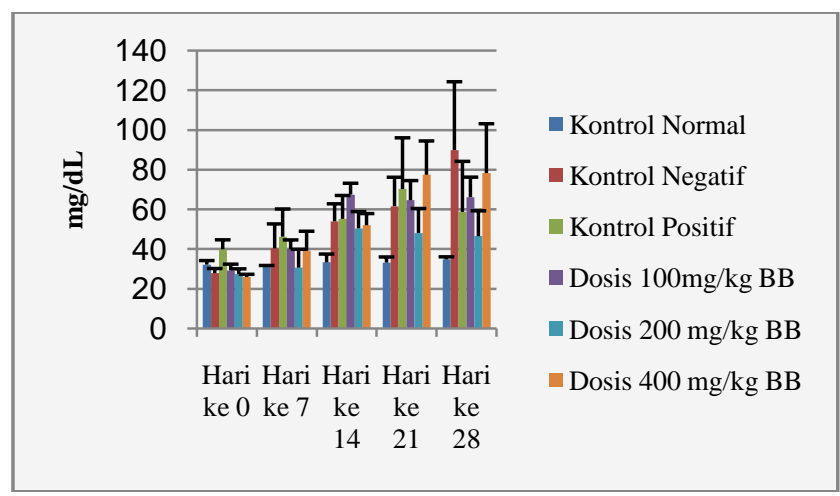

Gambar 2. Diagram profil kadar ureum darah tikus putih jantan setelah perlakuanpada masing masing kelompok hari ke-0, hari ke-7, hari ke-14, hari ke-21dan hari ke-28.

Tabel 3. Skoring tingkat kerusakan tubulus ginjal tikus

\begin{tabular}{|c|c|c|c|c|c|}
\hline \multirow[b]{2}{*}{ Kelompok Perlakuan } & \multirow{2}{*}{ Tikus } & \multicolumn{4}{|c|}{ Skoring kerusakan } \\
\hline & & 0 & 1 & 2 & 3 \\
\hline \multirow{5}{*}{ Kontrol Normal } & 1 & 0 & - & - & - \\
\hline & 2 & 0 & - & - & - \\
\hline & 3 & 0 & - & - & - \\
\hline & 4 & 0 & - & - & - \\
\hline & 5 & 0 & - & - & - \\
\hline Rata-rata & \multicolumn{5}{|c|}{0} \\
\hline \multirow{5}{*}{ Kontrol Negatif } & 1 & - & - & - & 3 \\
\hline & 2 & - & - & 2 & - \\
\hline & 3 & - & - & - & 3 \\
\hline & 4 & - & - & 2 & - \\
\hline & 5 & - & - & 2 & - \\
\hline Rata-rata & \multicolumn{5}{|c|}{2,4} \\
\hline \multirow{5}{*}{ Kontrol Positif } & 1 & 0 & - & - & - \\
\hline & 2 & 0 & - & - & - \\
\hline & 3 & - & 1 & - & - \\
\hline & 4 & 0 & - & - & - \\
\hline & 5 & 0 & - & - & - \\
\hline Rata-rata & \multicolumn{5}{|c|}{0,2} \\
\hline \multirow{5}{*}{ Dosis $100 \mathrm{mg} / \mathrm{kg} \mathrm{BB}$} & 1 & - & - & 2 & - \\
\hline & 2 & - & - & 2 & - \\
\hline & 3 & - & - & 2 & - \\
\hline & 4 & - & - & - & 3 \\
\hline & 5 & - & - & 2 & - \\
\hline Rata-rata & \multicolumn{5}{|c|}{2,2} \\
\hline \multirow{5}{*}{ Dosis $200 \mathrm{mg} / \mathrm{kg} \mathrm{BB}$} & 1 & - & - & 2 & - \\
\hline & 2 & - & 1 & - & - \\
\hline & 3 & - & - & 2 & - \\
\hline & 4 & - & - & 2 & - \\
\hline & 5 & - & - & 2 & - \\
\hline
\end{tabular}




\begin{tabular}{|c|c|c|c|c|c|}
\hline Rata-rata & \multicolumn{5}{|c|}{1,8} \\
\hline \multirow{3}{*}{ Dosis 400 mg/kg BB } & 1 & - & 1 & - & - \\
\cline { 2 - 6 } & 2 & - & 1 & - & - \\
\cline { 2 - 6 } & 3 & - & 1 & - & - \\
\cline { 2 - 6 } & 4 & 0 & - & - & - \\
\cline { 2 - 6 } & 5 & - & 1 & - & - \\
\hline Rata-rata & 5,8 \\
\hline
\end{tabular}

Keterangan :

Skor $\quad 0=$ Normal (tidak ada perubahan)

$1=$ tubular sel bengkak, beberapa sel piknotik dan necrotik (1/3 tubular sel necrotik)

$2=2 / 3$ sel tubular nekrotik

$3=>2 / 3$ tubular sel necrotik

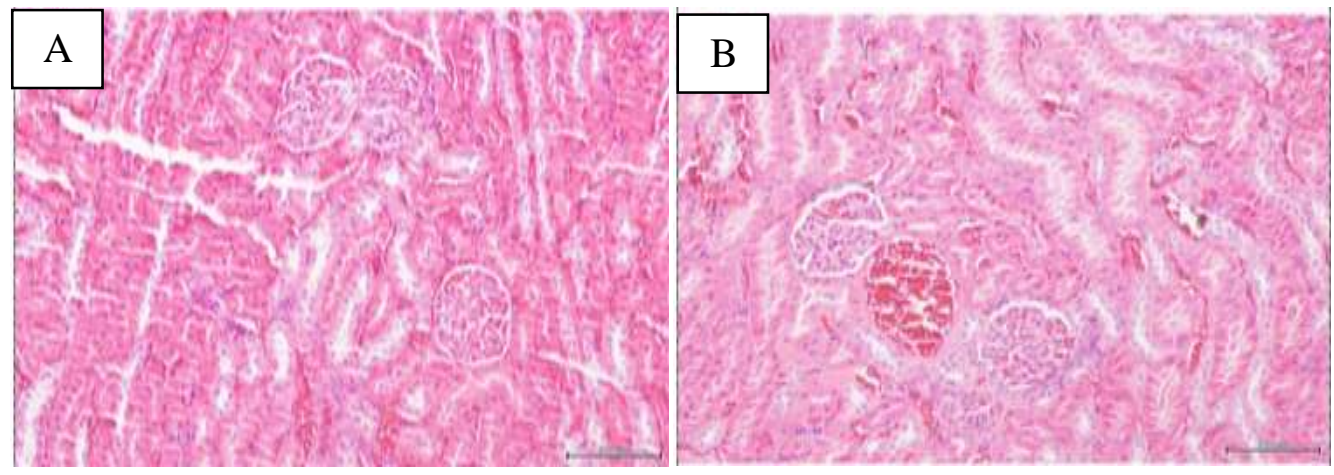

Gambar 3. Histologis tubulus ginjal tikus skor 0 pada kelompok normal dengan pewarnaan H\&E skala $100 \mu \mathrm{m}$

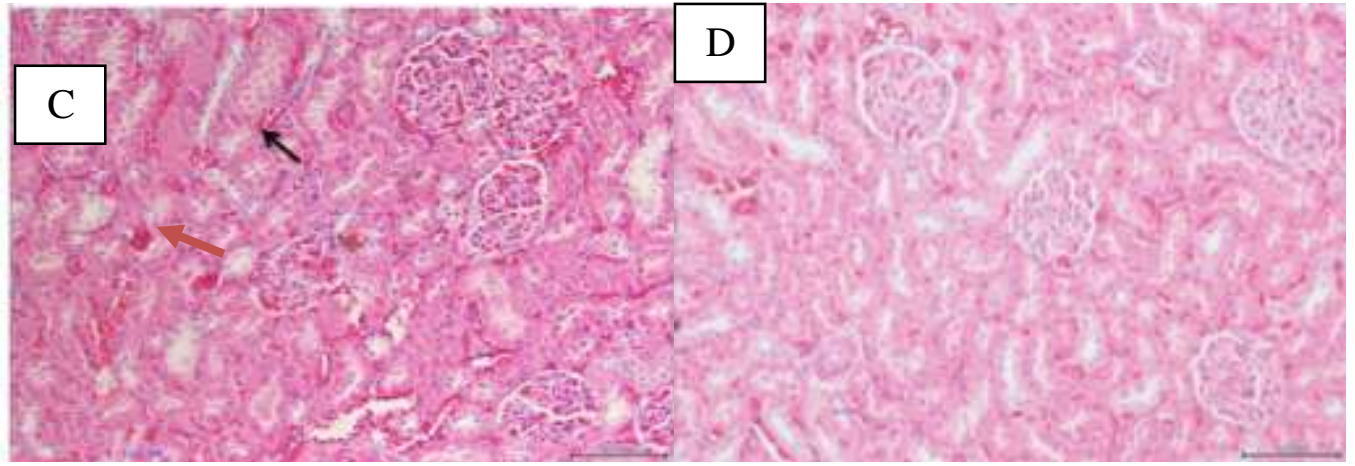

Gambar 4.Histologis tubulus ginjal tikus skor 1 (C) dan skor 0 (D) pada kelompok positif dengan pewarnaan H\&E skala $100 \mu \mathrm{m}$

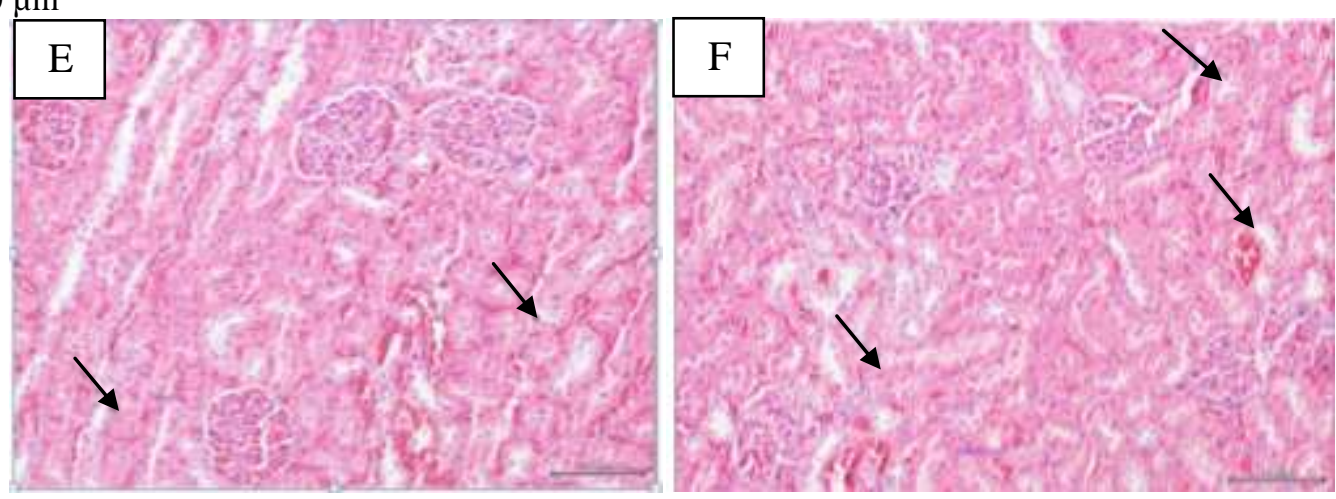

Gambar 5. Histologis tubulus ginjal tikus skor 2 (E) dan skor 3 (F) pada kelompok negatif dengan pewarnaan H\&E skala $100 \mu \mathrm{m}$ 

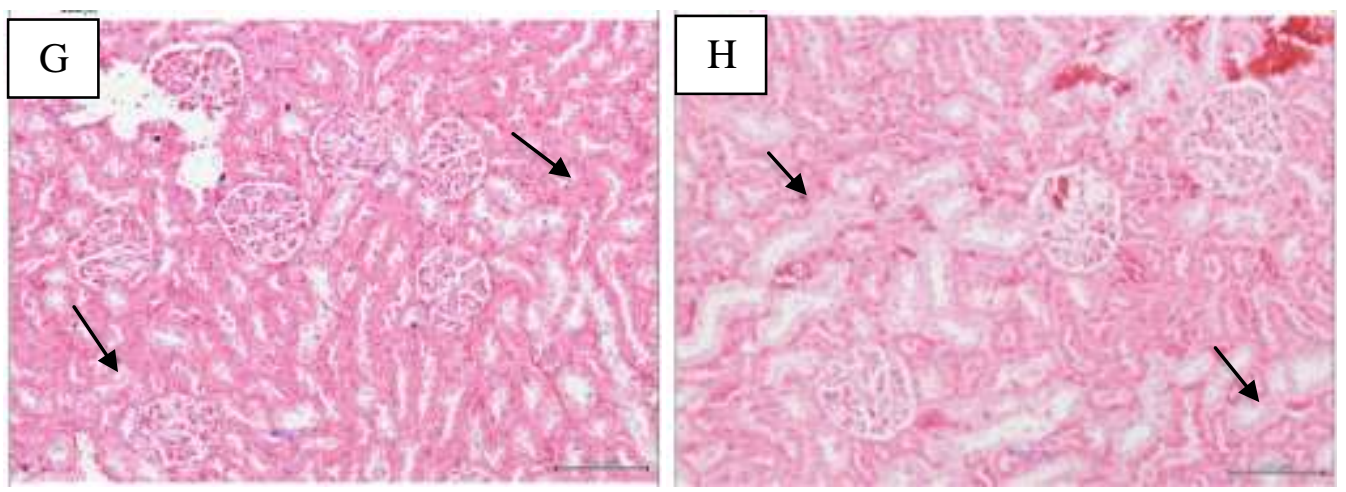

Gambar 6. Histologis tubulus ginjal tikus skor $2(\mathrm{G})$ dan skor $3(\mathrm{H})$ pada kelompok perlakuan dosis 100 dengan pewarnaan H\&E skala $100 \mu \mathrm{m}$

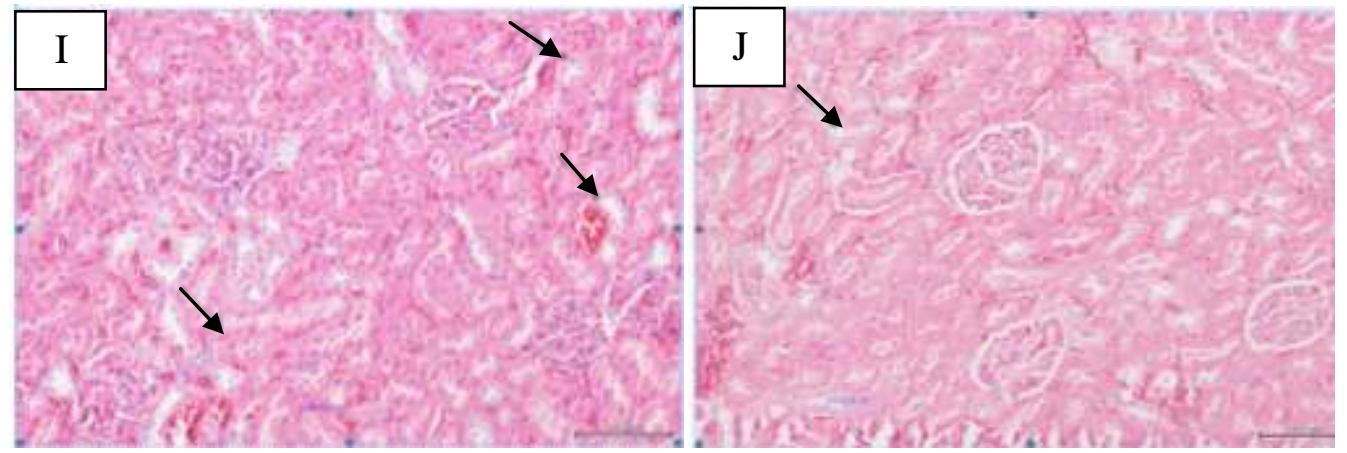

Gambar 7. Histologis tubulus ginjal tikus skor 2 (I) dan skor 1 (J) pada kelompok perlakuan dosis 200 dengan pewarnaan H\&E skala $100 \mu \mathrm{m}$

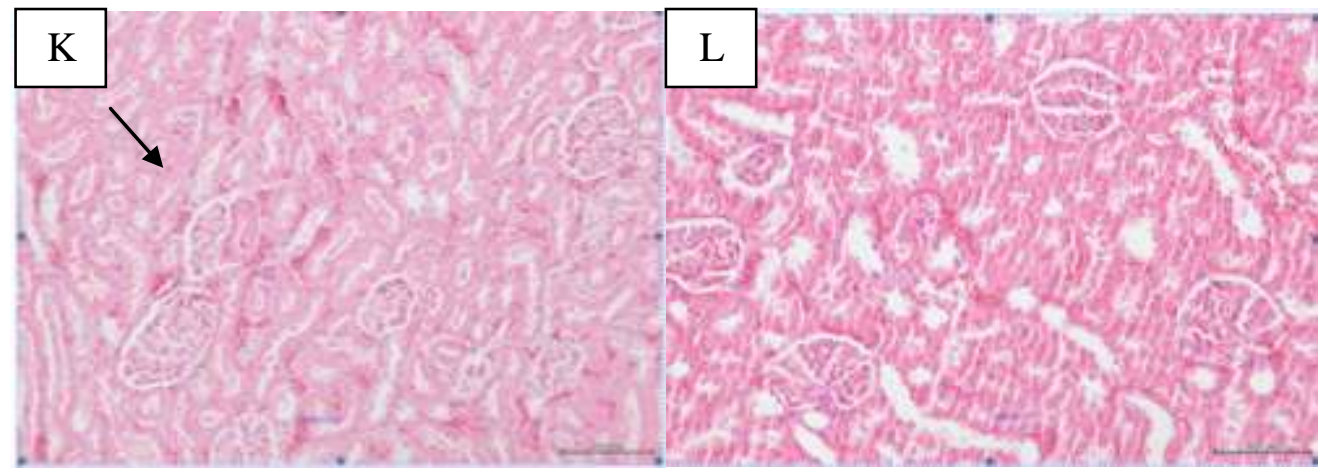

Gambar 8. Histologis tubulus ginjal tikus skor 1 (K) dan skor 0 (L) pada kelompok perlakuan dosis 400 dengan pewarnaan H\&E skala $100 \mu \mathrm{m}$

$$
\text { Keterangan: } \begin{aligned}
\longrightarrow & =\text { Sel tubulus ginjal bengkak } \\
& \longrightarrow=\text { Sel tubulus ginjal mengalami nekrosis }
\end{aligned}
$$

Peningkatan laju filtrasi glomerulus menyebabkan zat nefrotoksik yang masuk ke dalam ginjal akan dikeluarkan secara cepat akibat aktivitas urinisasi yang meningkat. Senyawa fenolik yang bersifat sebagai antioksidan dengan cara menangkal radikal bebas, sehingga sangat penting dalam mempertahankan keseimbangan antara oksidan dengan antioksidan di dalam tubuh, menetralisir efek toksik dari radikal bebas dengan cara mendonorkan ion hydrogen sehingga ion-ion menjadi stabil. 
Keadaan ion yang telah stabil menyebabkan menurunnya keadaan stress oksidatif di dalam jaringan, sehingga dapat menyebabkan peningkatan glomerular filtration rate (GFR).

Berdasarkan hasil pengamatan preparat histologis tubulus ginjal tikus putih jantan yang dapat dilihat pada tabel 3 dan dianalisis dengan uji KruskalWallis dilanjutkan dengan uji Mann-Whitney dengan parameter yang dilihat yaitu nekrosis, piknosis dan pembengkakan sel tubulus (Gambar 3,4,5,6,7,8). Ekstrak etanol daun gondola merah pada dosis 100, 200 dan $400 \mathrm{mg} / \mathrm{kg}$ BB sudah mempunyai efek terhadap tingkat kerusakan sel pada tubulus ginjal tikus putih jantan terutama pada dosis $400 \mathrm{mg} / \mathrm{kg} \mathrm{BB}$ yang mempunyai efek yang baik karena tingkat kerusakanya yang paling ringan. Hal ini terjadi karena dalam dosis tersebut terdapat zat aktif yang diduga dapat memberikan efek terhadap regenerasi sel pada tubulus ginjal tikus jumlahnya lebih banyak sehingga sel-sel yang mengalami kerusakan dalam ginjal bisa meregenerasi kembali. Efek tersebut disebabkan karena adanya kandungan senyawa seperti alkaloid, flavonoid, fenol, saponin dan tannin pada ekstrak etanol daun gondola merah yang berfungsi sebagai asupan antioksidan. Antioksidan berfungsi sebagai pertahanan tubuh terhadap radikal bebas yang menginduksi stress oksidatif dan senyawa oksigen reaktif dalam plasma dan sel sehingga kerusakan sel tidak terjadi.

\section{KESIMPULAN}

Berdasarkan hasil penelitian dan pembahasan maka dapat disimpulkan bahwa:

1. Ekstrak etanol daun gondola merah (Basella alba L.) mempunyai pengaruh terhadap kadar kreatinin dan ureum tikus putih jantan (Rattus norvegicus) diabetes yang diinduksi streptozotocin dengan dosis $40 \mathrm{mg} / \mathrm{kg}$ BB secara intraperitonial.

2. Ekstrak etanol daun gondola merah (Basella alba L.) dosis $200 \mathrm{mg} / \mathrm{kg}$ BB memberikan pengaruh yang signifikan terhadap penurunan kadar kreatinin dan ureum tikus putih jantan diabetes.

3. Ekstrak etanol daun gondola merah (Basella alba L.) dosis $400 \mathrm{mg} / \mathrm{kg}$ BB memiliki efek terhadap regenerasi sel pada tubulus ginjal tikus putih jantan (Rattus norvegicus) yang diinduksi streptozotocin.

\section{SARAN}

Ekstrak etanol daun gendola merah (Basella alba L.) bisa dijadikan modalitas terhadap terapi pada penderita nefropati diabetes, namun masih memerlukan penelitian dengan rancangan penelitian yang lebih baik, dan waktu penelitian yang lebih lama.

\section{DAFTAR PUSTAKA}

Departemen Perdagangan RI. (2011). Indonesian Herbal : The Traditional Therapy. Jakarta: Ministry of Trade Republic of Indonesia.

Fuadi, Akhmad. (2009). Pengaruh Ekstrak Etanol Daun Alpukat (Persea americana Mill) Terhadap Gambaran Ureum Dan Kreatinin Pada Tikus Putih Jantan Yang Diinduksi Etilen Glikol. (Skripsi), Fakultas Kedokteran Hewan, Institut Pertanian Bogor, Bogor.

Gerrit, Bevelander. (1988). Dasar-Dasar Histologi. Jakarta: Erlangga.

Kumar, Shankul., Prasad A. K., Iyer, S. V., Vaidya, S. K. (2013). Systematic pharmacognostical, phytochemical and pharmacological review on an ethno medicinal plant, Basella alba L. Journal of Pharmacognosy and Phytotherapy. 57.

Nantia, Edouard A, Manfo, Faustin P. T, Beboy, Nathalie S. E, F. Moundipa, Paul.(2013). In vitro antioxidant activity of the methanol extract of basella alba $\mathrm{L}$ (Basellaceae) in rat testicular homogenat. (Dissertation), University of bamenda, balimbi, Cameroon.

Robbins S.J., Cotran R.S., Kumar Vinay. (2003). Basic Pathology. Edisi 7th. Philladelphia. Saunders.

Sari, D.P. (2016) Efek anti diabetes ekstrak etanol daun asam jawa (TamarindusindicaLinn) terhadap tikus putih jantan (Rattus norvegicus) yang diinduksi streptozotocin. (Skripsi), Sekolah Tinggi Ilmu Farmasi Pelita Mas, Palu. 
Scobie, IN. 2007. Atlas of Diabetes MellitusThird Edition. London : Informa Healthcare.

Nirmala, A., Saroja, S., R.Vasanthi, H., Lalita, G.2009. Hypoglycemic Effect of Basella Rubra In Streptozotocin Induced Diabetic Albino Rats. Sri Ramachandra University. India. Hal 25 